\title{
PEMETAAN DAN ANALISIS KNOWLEDGE SHARING PADA SITUS FORUM KOMUNITAS ONLINE KASKUS
}

\author{
Binsar Tampahan Siagian dan Dana Indra Sensuse
}

Program Studi Magister Teknologi Informasi, Fakultas Ilmu Komputer, Universitas Indonesia, Jalan

Salemba Raya 4, Jakarta Pusat 10430, Indonesia

E-mail: bi_tamp300682@yahoo.com

\begin{abstract}
Abstrak
Salah satu kelebihan forum online adalah sifatnya yang asynchronous, semua orang dapat membagikan pengetahuan maupun menanyakan informasi, kapan saja dan di mana saja. Knowledge sharing di forum, umumnya melalui pengiriman pesan. Namun, pola knowledge sharing tersebut sering tidak terpantau oleh pengelola forum, yang kebanyakan hanya mengandalkan data statistik biasa dalam menilai kinerja forum mereka, seperti jumlah kunjungan atau jumlah balasan suatu thread. Oleh karena itu, dalam penelitian ini akan digunakan metode Social Network Analysis (SNA) yang paling tepat dalam mengukur model atau pola knowledge sharing tersebut. Objek penelitian ini adalah suatu forum terbesar di Indonesia, yaitu Forum Kaskus, khususnya pada threads Forum Programmer yang berada di sub forum Computer Stuff. Visualisasi dan analisis dari pola interaksi di dalam forum tersebut akan dibahas dalam penelitian ini. Hasil dari penelitian ini adalah didapatkannya suatu model knowledge sharing dalam forum tersebut, yang sangat berguna untuk menilai Forum Kaskus khususnya pada knowledge sharing di dalamnya.
\end{abstract}

Kata Kunci: forum kaskus, knowledge sharing

\begin{abstract}
One of the advantages of online forums is that they are asynchronous, which people can share knowledge and ask for information, anytime and anywhere. Knowledge sharing in the forum, generally through the delivery of the message. However, the pattern of knowledge sharing is often not monitored by the management forum, which mostly rely on statistical data used to assess the performance of their forum, such as the number of visits or the number of replies a thread. Therefore, in this study will use methods of Social Network Analysis (SNA) is the most appropriate measure or model the patterns of knowledge sharing. Object of this study is a forum in Indonesia, that is Kaskus Forum particularly in Programmer Forum threads that are in the sub forum Computer Stuff. Visualization and analysis of patterns of interaction in the forum will be addressed in this study. The results of this study is the obtainment of a model of knowledge sharing in the forum, which is very useful for assessing Kaskus Forum especially on knowledge sharing in it
\end{abstract}

Keywords: kaskus forum, knowledge sharing

\section{Pendahuluan}

Saat ini, komunikasi bercabang (threaded) merupakan salah satu cara berinteraksi yang umum dalam dunia maya. Jenis komunikasi tersebut terjadi di dalam forum web, e-mail, wiki, newsgroup, dan blog. Ketika manusia secara sistematis berpartisipasi dalam cara yang khusus, dapat dilihat bahwa mereka sedang memainkan sebuah peran sosial di dalamnya [1].

Untuk memahami dan mengenali peran sosial seorang individu dalam suatu komunitas diperlukan sebuah tools yang mampu menggambarkan dan menganalisis pola interaksi yang terjadi di dalam komunitas tersebut. Dengan mengetahui peran sosialnya, banyak manfaat yang diharapkan dapat diperoleh untuk perkembangan dan kemajuan komunitas tersebut. [2] menyatakan bahwa dengan memahami pola interaksi suatu komunitas, bukan saja bermanfaat untuk bisa merangkulnya, melainkan juga memengaruhi dan mendorongnya ke arah tipe komunitas yang diinginkan.

Forum komunitas online memang merupakan salah satu media untuk menyebarluaskan informasi dan pengetahuan antar member-nya, bisa dilakukan kapan saja dan di mana saja, serta yang paling penting adalah tidak harus dalam waktu yang bersamaan dengan rekan yang diajak berinteraksi. Di dalam forum tersebut masing-masing member berinteraksi di 
dalam komunitas-komunitas yang terbagi berdasarkan topik permasalahan yang dibahas.

Freeman [3] menjelaskan mengenai analisis jejaring sosial bahwa analisis jejaring sosial terpusat pada penemuan pola interaksi masyarakat. Analisis jejaring meyakini bahwa bagaimana seorang individu hidup sangat bergantung kepada bagaimana individu tersebut terikat ke dalam jaringan hubungan-hubungan sosial yang lebih luas.

Forum Kaskus adalah forum komunitas online terbesar di Indonesia dari sisi kesibukan/traffic, hal ini dikarenakan basis anggotanya yang paling besar saat ini (Alexa.com, November 2009). Namun hal tersebut hanya jika dilihat dari perhitungan terhadap data statistik yakni mengenai kesibukan situsnya dan jumlah member yang terdaftar. Erlin [4] menyatakan bahwa data statistik yang tersedia di dalam suatu forum diskusi seperti jumlah anggota, jumlah kunjungan setiap hari, jumlah pesan yang dikirim atau di-post setiap hari, dan sebagainya tidak cukup memberikan gambaran mengenai interaksi yang terjadi di dalam forum tersebut. Data statistik tersebut tidak dapat memberikan gambaran mengenai struktur komunikasi, tingkat partisipasi dari setiap member, dan karakteristik struktural lainnya dari suatu forum. Hal ini yang menyebabkan orang tidak dapat menilai partisipasi dan interaksi di antara member yang ada di forum tersebut.

Maka dari itu, diperlukan suatu metode yang dapat menilai atau memeriksa pola interaksi di antara member dalam suatu forum, untuk menilai dan menyelidiki bagaimana sebenarnya model knowledge sharing dalam forum online seperti Forum Kaskus, perlu dilakukan suatu visualisasi dan analisis tentang pola interaksi yang ada di dalamnya [5]. Dalam penelitian ini, akan digunakan metode analisis Social Network Analysis untuk memvisualisasikan dan menganalisis pola interaksi member di dalam Forum Kaskus. Demikianlah penelitian ini dilakukan untuk menjawab pertanyaan "Bagaimanamodel knowledge sharing yang terjadi dalam forum komunitas online terbesar di Indonesia (yaitu Forum Kaskus)?”.

Data, informasi dan pengetahuan memiliki pengertian yang berdekatan, walaupun begitu ada banyak definisi yang dapat ditemukan mengenai ketiganya. Untuk mendapatkan pengertian yang menyeluruh mengenai data, informasi dan pengetahuan, berikut ini disajikan beberapa definisi dari ketiganya dari beberapa ahli.

Gurteen [6] menggunakan perumpamaan tentang membuat kue untuk mengilustrasikan perbedaan dari ketiganya; dari komponenkomponen molekul dari kue (data), sampai ke daftar bahan-bahan (informasi), melalui sebuah resep (pengetahuan eksplisit), sehingga bisa membuat kue yang nikmat dari resep tersebut (pengetahuan tacit).

Sedangkan definisi menurut Davenport dan Prusak (2005), data adalah himpunan fakta yang diskrit dan terpisah mengenai suatu peristiwa yang terjadi dalam suatu hubungan organisasi, biasanya disimpan di dalam dokumen dan arsip perusahaan/organisasi melalui suatu infrastruktur teknologi. Informasi adalah data yang memiliki nilai tambah, yakni, data yang sudah diolah/diubah untuk mendapatkan utilitas, arti dan konteks yang diinginkan. Sedangkan pengetahuan adalah campuran dari pengalaman, nilai, informasi kontekstual, pandangan pakar dan intuisi mendasar yang memberikan suatu lingkungan dan kerangka untuk mengevaluasi dan menyatukan pengalaman baru dengan informasi.

Pengetahuan dapat dibedakan dari data dan informasi dengan dua cara [7]. Cara pertama yaitu, cara pandang yang sederhana dengan menempatkan pengetahuan pada level tertinggi dalam suatu hierarki, sementara informasi pada level menengah dan data pada level terendah. Berdasarkan cara pandang ini, pengetahuan merujuk kepada informasi yang mendukung pengambilan tindakan dan keputusan, atau informasi yang dilengkapi dengan petunjuk. Berdasarkan cara pandang ini, data merujuk kepada fakta murni yang tidak mengandung suatu konteks, sedangkan informasi dilihat sebagai suatu data yang sudah memiliki konteks. Cara kedua yaitu, dengan mendefinisikan pengetahuan berada di dalam suatu wilayah sebagaimana menunjukkan kebenaran mengenai hubungan antara konsep-konsep yang berkaitan dengan wilayah khusus tersebut.

Menurut becerra-fernandez [7], pengetahuan dapat dibagi menjadi dua jenis yaitu pengetahuan eksplisit (explicit knowledge) dan pengetahuan implisit (tacit knowledge). Pengetahuan eksplisit adalah sesuatu yang diekspresikan dengan katakata dan angka, serta dapat disampaikan dalam bentuk ilmiah, spesifikasi, manual dan sebagainya. Pengetahuan jenis ini dapat segera diteruskan dari suatu individu ke individu lainnya secara formal dan sistematis. Pengetahuan eksplisit juga dapat dijelaskan sebagai suatu proses, metode, cara, pola bisnis dan pengalaman desain dari suatu produksi. Pengetahuan implisit adalah pengetahuan dari pakar, baik individu maupun masyarakat, serta pengalaman mereka. Pengetahuan implisit bersifat sangat personal dan sulit dirumuskan sehingga membuatnya sangat sulit untuk dikomunikasikan atau disampaikan kepada orang lain. Perasaan pribadi, intuisi, bahasa tubuh, pengalaman fisik serta petunjuk 
praktis (rule-of-thumb) termasuk dalam jenis pengetahuan implisit.

Level atau tingkatan dari pengetahuan yaitu, know-what, know-how, know-why, care-why. Level know-what berkaitan dengan pengetahuan kognitif (proses mengetahui). Seseorang yang mengetahui suatu ilmu belum tentu dapat menerapkan ilmu tersebut dalam kehidupan sehari-harinya. Level know-how berkaitan dengan kemampuan seseorang untuk mengubah/menerjemahkan pengetahuan yang dimiliki (know-what) menjadi pengetahuan yang diaplikasikan nyata. Hal yang terpenting pada level ini bukan pada mengetahui lagi, tetapi pada kemampuan untuk mengubah atau menerjemahkannya ke dalam pekerjaan yang nyata. Level know-why berkaitan dengan pengetahuan yang lebih kompleks dan hubungan sebab-akibat suatu peristiwa. Pengetahuan ini memungkinkan seseorang untuk maju satu tahap dari level know-how dan menciptakan kemampuan yang istimewa dalam penggunaan pengetahuan yaitu kemampuan untuk berurusan dengan hal-hal yang tidak dapat diprediksi dan situasi yang tidak dapat dilihat. Pada level ini, terjadi penggabungan beberapa pengetahuan yang dimiliki untuk menghasilkan suatu pengetahuan (intuisi) dalam menghadapi suatu permasalahan. Level care-why berkaitan dengan kreativitas dan motivasi. Level ini juga menjelaskan bagaimana kreativitas, motivasi yang tinggi dan semangat bekerja dapat menghasilkan sesuatu atau nilai tambah bagi suatu organisasi/perusahaan dengan menggunakan uang dan sumber daya yang tersedia. Level ini juga bisa disebut sebagai budaya organisasi atau perusahaan.

Dalam manajemen pengetahuan (knowledge management), knowledge sharing merupakan salah satu bagian dari proses-proses manajemen pengetahuan. Tiwana [8] menjelaskan bahwa dalam manajemen pengetahuan, diharapkan jika seorang karyawan mempelajari sesuatu maka karyawan lainnya di dalam organisasi atau perusahaan tersebut juga mengetahui atau mengerti apa yang dipelajari oleh karyawan tersebut. Oleh karena itu, diperlukan knowledge sharing yang efektif supaya manajemen pengetahuan berhasil dijalankan dalam suatu organisasi atau perusahaan.

Becerra-Fernandez [7] menjelaskan bahwa knowledge sharing adalah sebuah proses di mana pengetahuan eksplisit atau tacit dikomunikasikan kepada individu lainnya. Menurutnya pula, ada tiga penjelasan mengenai knowledge sharing yakni: (1) knowledge sharing berarti transfer/pemindahan yang efektif, sehingga penerima pengetahuan tersebut dapat memahaminya untuk dapat melakukannya dengan cara yang benar; (2) dalam knowledge sharing, yang dibagikan adalah pengetahuan itu sendiri daripada rekomendasi-rekomendasi berdasarkan pengetahuan tersebut; (3) knowledge sharing dapat dilakukan antar individu demikian juga antar kelompok, antar departemen atau antar organisasi.

Menurut Poonkundran [9] ada beberapa alasan seseorang untuk membagi pengetahuan yang memotivasi orang tersebut, antara lain: (1) pengetahuan itu mudah rusak atau hilang. Pengetahuan memiliki waktu hidup yang singkat. Jika tidak digunakan maka dengan cepat akan kehilangan nilainya; (2) jika tidak produktif dalam menghasilkan pengetahuan lalu orang lain yang memiliki pengetahuan yang sama akan melakukannya, walaupun dengan rendahnya tingkat knowledge sharing yang terjadi pada saat ini. Dapat dijamin bahwa secemerlang apapun ide yang dimiliki seseorang dalam suatu organisasi, orang lain yang berada di tempat lain dalam organisasi tersebut akan berpikir di jalan yang sama; (3) dengan membagikan pengetahuan, kita akan memeroleh lebih banyak dari yang kita berikan. Pembagian pengetahuan merupakan sebuah proses yang sinergis. Misalnya jika membagikan ide atau gagasan dengan orang lain melalui tulisan, maka kita akan mendapatkan umpan balik yang dapat membentuk dan mengembangkan ide atau gagasan tersebut.

Saat ini, agar dapat menyelesaikan lebih banyak pekerjaan dalam sebuah organisasi membutuhkan sebuah usaha yang sifatnya kerja sama atau kolaborasi. Jika kita mencoba berjalan sendiri-sendiri, maka sangat mungkin untuk jatuh, kita tidak saja hanya membutuhkan masukan dari orang lain, melainkan yang lebih utama adalah adanya dukungan dari orang lain.

Cheung [10] menerangkan bahwa pemetaan pengetahuan (knowledge mapping) adalah suatu proses menilai dan menghubungkan informasi, pengetahuan dan kompetensi yang dimiliki oleh seorang individu dan suatu kelompok di dalam sebuah organisasi. Pemetaan pengetahuan adalah proses pembuatan peta pengetahuan. Peta pengetahuan (knowledge map) adalah gambaran dari satu atau lebih aspek pengetahuan yang tersedia dalam sebuah organisasi dengan tujuan untuk memenuhi kebutuhan informasi yang khusus bagi satu atau lebih peran/jabatan pekerja di dalam organisasi tersebut [11]. Sedangkan ide yang mendasari pemetaan pengetahuan sejalan dengan knowledge sharing yaitu mendorong para profesional untuk membagikan informasi kepada orang lain, proyek, organisasi dan perangkat di dalam lapangan kerja mereka [12].

Van den Berg dan Popescu [12] juga mendefinisikan bahwa peta pengetahuan adalah 
teknik dan perangkat untuk memvisualisasikan pengetahuan dan hubungan-hubungannya ke dalam suatu bentuk yang jelas di mana dengan cara tersebut fitur-fitur yang bersesuaian dapat digarisbawahi. Peta pengetahuan merupakan alat atau perangkat yang digunakan dalam manajemen pengetahuan, dapat digunakan untuk memperlihatkan, membagikan, mempelajari, dan menciptakan pengetahuan sebaik mungkin untuk memungkinkan pengambilan keputusan yang lebih baik, menilai budaya pengetahuan dari suatu organisasi dan mengatasi hal-hal yang bertentangan atau berselisihan [12].

Cheung [10] menjelaskan bahwa tujuan dari pembuatan peta pengetahuan adalah untuk mengidentifikasi di mana pengetahuan berada sehingga pengguna pengetahuan tersebut dapat dengan mudah mengakses pengetahuan yang diinginkan. Ebener [13] menyatakan bahwa agar efektif, peta pengetahuan yang ingin dihasilkan haruslah dibuat dengan merujuk kepada empat perspektif, dikenal dengan kerangka kerja visual yakni, fungsi peta (meliputi koordinasi, motivasi dan elaborasi/uraian), tipe pengetahuan (know what, know how, know why, know where, know who), penerima/pengguna peta (individu, kelompok, organisasi, jaringan), tipe visualisasi (sketsa, diagram, gambar atau peta)

Keberhasilan dari suatu proses pemetaan pengetahuan bergantung pada besarnya jangkauan dari orang yang mengaplikasikannya, kemampuan untuk mengikat seluruh orang atau pihak dalam pengaplikasiannya, memastikan bahwa orang lain dapat memahami prosesnya dan mampu untuk menafsirkan peta tersebut, dan penggabungan dari keempat perspektif kerangka kerja visual yang disebutkan di atas. Keberhasilan pemetaan pengetahuan bukan dilihat dari keberhasilan menggunakan perangkat untuk menghasilkan peta [13].

Analisis jejaring sosial adalah suatu teknik untuk mempelajari hubungan atau relasi sosial antar anggota dari sebuah kelompok orang [14]. Pemetaan pengetahuan dalam kerangka Social Network Analysis bisa divisualisasikan atau diwakilkan oleh bentuk matriks dan grafik. Teori matriks yang digunakan dalam menggambarkan jejaring sosial sama dengan teori matriks pada umumnya. Di mana masing-masing sel menyimpan nilai atau tanda dari hubungan yang ada antara baris dan kolom yang bersesuaian. Matriks ini disebut sebagai matriks adjacency atau matriks bersesuaian/ketetanggaan. Hanneman and Riddle [14] menjelaskan bahwa para analis menggunakan hanya satu jenis dari sekian banyak graf yaitu graf yang terdiri dari titik-titik (nodes) yang menggambarkan aktor dan garis (edges) yang menggambarkan hubungan. Istilah graf berarah, graf bertanda atau graf berasal dari para ahli matematika, istilah tersebut digunakan untuk menggambarkan suatu jejaring sosial oleh para ahli sosiologi dengan sebutan sosiogram.

Sosiogram adalah graf, dan mengikuti kaidah maupun peraturan dari graf itu sendiri. Termasuk jenis dari sosiogram yang dapat dibagi menjadi beberapa jenis berdasarkan tingkat pengukuran hubungannya (bertanda, binary atau bernilai), banyaknya jenis hubungannya (simplex atau multiplex), dan arah hubungannya (berarah atau tidak).

Dalam analisis sebuah jejaring dengan menggunakan metode analisis jejaring sosial, ada beberapa ukuran dasar yang menjadi titik tolak perhitungan matematis untuk mengetahui pola keterhubungan dalam jejaring tersebut. Ukuran dasar yang digunakan antara lain: besar jejaring (network size), derajat (degree), kepadatan (density), ketergapaian (reachability), keterhubungan (connectivity), jarak (distance), dan jalur (flow) informasi. Besarnya jejaring sangat penting untuk mengetahui lingkup penelitian yang dilakukan dan memberikan batasan-batasan kepada kesimpulan yang dapat dihasilkan.

Ukuran jejaring penting untuk struktur hubungan sosial karena keterbatasan sumber daya dan kapasitas bagi setiap aktor untuk membangun dan menjaga hubungan [14]. Kepadatan sebuah jejaring adalah perbandingan antara semua hubungan yang ada dengan semua hubungan yang mungkin ada. Kepadatan sebuah jejaring dapat memberitahu kita tentang bagaimana informasi bergerak antara titik-titik dalam jejaring tersebut dan juga aktor mana yang memiliki modal sosial yang tinggi.

Sentralitas adalah sifat dasar dari sebuah struktur sosial. Sentralitas sosial dalam sebuah jaringan sosial timbul dari hubungan yang dimiliki sebuah titik terhadap titik yang lain [14]. Analisis sentralitas dalam sebuah jejaring sosial dapat memberikan pengetahuan tentang peran seseorang individu dalam lingkungannya. Sentralitas Derajat (Degree Centrality), Sentralitas Kedekatan (Closeness Centrality) dan Sentralitas Perantara (Betweenness Centrality).

Komponen dari suatu jejaring atau graf adalah subgraf yang terdiri dari kumpulankumpulan node yang saling terhubung di dalamnya, namun antara subgraf yang satu dengan yang lain tidak terhubung. Jika sebuah subgraf memiliki beberapa node terisolasi, maka aktor tersebut termasuk sebuah komponen yang terdiri dari satu node [14].

Hanneman dan Riddle [14] menyatakan bahwa analisis berdasarkan perantara/penghubung dalam suatu jaringan, bertujuan untuk 
mengidentifikasi aktor yang menempati posisi strategis dalam penyebaran atau aliran knowledge (aktor yang berperan sebagai penghubung bagi aktor/grup lainnya yang tidak saling terhubung sebelumnya). Ukuran yang dapat digunakan adalah bridge dan cut point.

Cut point, yakni aktor-aktor yang jika dihapus dari suatu jejaring akan memecah jejaring tersebut menjadi bagian-bagian yang terpisah dan bagian-bagian tersebut disebut blok-blok yang merupakan bagian dengan jumlah node maksimum yang tidak bisa dipisahkan lagi [14].

Willging [5] meneliti interaksi yang terjadi pada sebuah forum online yang asynchronous dengan menggunakan teknik dan visualiasi SNA. Metode tersebut digunakan untuk membangun sebuah objek visual yang dapat menggambarkan interaksi yang terjadi secara online dan kegunaan dari gambaran tersebut adalah sebagai alat untuk pengenalan akan struktur data. Dalam penelitian ini, sebuah kelas online akan diteliti dengan tujuan untuk membawa pengetahuan baru akan interaksi online dan perangkat penguji untuk menilai kualitas dari interaksi-interaksi yang terjadi di dalamnya.

Sampel yang diuji dalam penelitian ini adalah sebuah kelas yang dibentuk melalui media Blackboard, yaitu sebuah sistem manajemen pembelajaran online, yang menjadi sumber data mengenai interaksi. Lingkungan utama dalam kelas interaksi ini adalah media asynchronousnya. Kelas tersebut terdiri atas mahasiswa yang mengikuti mata kuliah ketiga pada suatu program Magister Pendidikan online yang harus menyelesaikan delapan mata kuliah. Penelitian dilakukan pada akhir tahun pertama dari program tersebut (sekitar masa pertengahan ke akhir dari program tersebut). Penelitian dengan kasus ini, pada sebuah kelas atau forum online, menunjukkan bahwa SNA memberikan informasi yang berguna mengenai interaksi yang dilakukan secara maya dalam sebuah media asynchronous. Ukuran metrik dan gambaran tiga dimensi dari SNA mampu menyatakan karakteristik struktural dari sebuah kelompok atau forum, mengidentifikasi anggota yang berperan sentral, penghubung (bridge), dan yang terisolasi dalam sebuah kelas. Teknik ini merupakan alat yang sangat bagus sebagai metode analisis untuk mengevaluasi dan mengawasi interaksi-interaksi online.

Jika dipadukan ke dalam Sistem Manajemen Pembelajaran, teknik tersebut dapat memberikan bantuan secara sosial dan visual kepada para instruktor dan mahasiswa, membuat mereka semakin sadar akan pentingnya membangun hubungan sosial dalam sebuah kelas.
Penelitian yang dilakukan [4] berdasarkan permasalahan di mana sistem manajemen pembelajaran atau learning management system (LMS) yang ada pada saat itu belum mampu menyediakan informasi seperti struktur komunikasi dari kelompok yang ada, tingkat partisipasi dari masing-masing individu, identifikasi siapa yang menjadi aktor sentral dan karakteristik struktural lainnya dari sebuah forum diskusi. Kemudian instruktur dari sebuah kelas online tidak diberi indikator struktural yang memungkinkan mereka untuk mengevaluasi partisipasi dan interaksi di antara murid-murid kelasnya. Contohnya saja, hanya informasi statistik, seperti diberikan informasi mengenai frekuensi dari jumlah posting-an, tetapi hal tersebut bukan ukuran yang paling sesuai digunakan untuk mengukur aktivitas atau pola interaksi.

Penelitian ini dilakukan dengan menganalisis interaksi antara murid-murid dalam sebuah forum diskusi online yang asynchronous dengan menggunakan metode SNA. Penelitian ini menghasilkan kesimpulan bahwa SNA menyediakan sebuah analisis interaksi murid yang lebih berguna dalam hal berkaitan dengan informasi tentang struktur komunikasi yang bisa disediakan. Hal ini dapat digunakan oleh seorang instruktur untuk menilai interaksi sosial dalam hal parameter struktur jejaring [4].

Penelitian [15] berjudul Pengaplikasian Social Network Analysis dalam sebuah forum online yang anggotanya adalah pengajar/guru. Penelitian ini berangkat dari permasalahan bahwa pada saat itu tidak ditemukan penelitian terhadap forum online yang anggotanya adalah pengajar, yang telah menilai atau memeriksa interaksi dari pesan online yang ada di forum tersebut. Karena menurut mereka interaksi atau relasi dari pesanpesan dalam forum tersebut menawarkan wawasan yang penting bagi fungsi dari forum online dengan menafsirkan pesan-pesan yang dipost oleh pengajar tidak sebagai unit pesan yang berdiri sendiri, melainkan sebagai wujud dari suatu relasi. Oleh karena itu, penelitian ini dilakukan dalam upaya untuk menganalisis celah atau gap ini dengan memeriksa sebuah forum online yang beranggotakan pengajar dalam kaitannya dengan relasi dari pesan-pesan yang mereka kirim kepada pengajar lainnya. Penelitian ini menggabungkan gagasan jejaring sosial untuk mengidentifikasikan pola komunikasi online dari para pengajar tersebut.

Perangkat lunak yang digunakan dalam penelitian ini adalah UCINET, program komputer untuk menganalisis jejaring sosial, dan NetDraw, program komputer yang digunakan untuk memvisualisasikan data jejaring. 


\section{Metodologi}

Berdasarkan landasan teori yang telah dipelajari dan dibahas dalam bagian sebelumnya, maka dibentuklah pola pikir yang akan digunakan dalam penelitian ini. Pola pikir ini merupakan kerangka dasar untuk pelaksanaan penelitian ini, menjelaskan metode dan perangkat-perangkat lain yang digunakan dalam setiap langkah-langkah penelitian ini.

Pengumpulan data dilakukan dengan metode observasi pada studi kasus yakni Forum Kaskus. Sesuai dengan tujuan penelitian bahwa objek yang diteliti dalam forum tersebut adalah interaksi pesan yang terjadi antar member pada Forum Kaskus, khususnya di threads Programmer Forum pada sub forum Computer Stuff, yang dikirim selama bulan Mei 2009. Karena metode analisis yang akan digunakan adalah Social Network Analysis, maka yang dibutuhkan adalah data mengenai relasi atau interaksi antar individu yang ada di dalam suatu jejaring untuk menemukan pola interaksi dari jejaring tersebut [3].

Di dalam forum seperti Kaskus, member di dalamnya berinteraksi dengan cara komunikasi bercabang (threaded) yakni masing-masing member dapat mengirimkan pesan (bisa berupa pertanyaan, informasi, maupun pengumuman) ke dalam forum dengan struktur yang bercabang sesuai dengan topik bahasan tertentu. Setiap member juga dapat saling membalas pesan dalam forum tersebut dengan cara membuka pesan dengan topik tertentu untuk membalasnya, lalu pesan balasan tersebut hanya akan memiliki relasi dengan pesan pertama yang dibalas oleh member tersebut. Pesan balasan inilah yang akan direkam ke dalam suatu matriks yang dinamakan matriks bersesuaian (adjacency) untuk nantinya digunakan untuk mengetahui pola relasi dalam forum tersebut.

Matriks bersesuaian tersebut merekam relasi yang muncul antar member dalam forum tersebut. Dalam sebuah forum, seorang member A bisa saja mengirimkan pesan kepada pesan yang dibuat oleh member $\mathrm{B}$, namun belum tentu member $\mathrm{B}$ tersebut pernah memberikan pesan balasan kepada pesan yang dibuat oleh member A. Sehingga matriks bersesuaian yang tepat untuk merekam interaksi-interaksi tersebut adalah matriks asymetric di mana baris i dapat saja memiliki hubungan dengan kolom $\mathrm{j}$ namun belum tentu sama untuk sebaliknya. Untuk menggambarkan adanya relasi ke dalam suatu matriks dapat dilakukan dengan memberikan nilai tertentu untuk setiap pesan balasan yang dikirimkan oleh seorang member kepada member lain. Pada penelitian ini, agar dapat diukur rata-rata pesan yang dikirim oleh setiap member dalam forum ke member lain dalam forum tersebut, maka pada setiap pesan balasan yang ada akan direkam ke dalam matriks dengan menambahkan nilai 1 pada setiap sel yang terdapat relasi (seluruh sel matriks awalnya diisi dengan nilai 0). Jumlah dari angka dalam setiap sel menunjukkan banyaknya pesan yang dikirim oleh member pada baris i ke member pada kolom j yang bersesuaian.

Data utama berasal dari interaksi antara pesan-pesan yang ada di setiap thread yang termasuk dalam lingkup penelitian yakni yang termasuk di dalam sub forum Computer Stuff yakni threads Programmer Forum dan yang dikirim selama bulan Mei 2009. Data lain yang dibutuhkan juga untuk mendukung penelitian ini berupa data-data yang didapat dari pengamatan terhadap Forum Kaskus, seperti, profil aktor yang diamati (klasifikasi member, jenis kelamin, jumlah pesan yang telah di-post, tanggal bergabung di Forum Kaskus) dan informasi mengenai thread yang diteliti (siapa yang memulai/mengirim pesan pertama, jumlah member yang melihat dan membalas pesan, tanggal mulai pesan di-posting).

Data yang terkumpul dalam penelitian ini dapat dibagi menjadi dua jenis yakni data mengenai relasi yang terjadi antara member dan juga data statistik lainnya yang didapat selama observasi terhadap forum. Dalam tahap ini akan diproses dan dilakukan analisis awal terhadap data statistik lain untuk mendapatkan gambaran awal terhadap sampel penelitian.

Metode yang digunakan adalah metode statistik deskriptif untuk menggambarkan kondisi sampel yang diteliti. Adapun gambaran awal mengenai sampel itu meliputi, data statistik member (jumlah member berdasarkan klasifikasinya, jenis kelamin, tanggal mendaftar di forum, dan banyaknya member tersebut menjadi thread starter) dan data statistik thread (jumlah thread jika dihubungkan dengan klasifikasi member, jumlah member melihat dan membalas suatu thread) yang menjadi objek penelitian. Perangkat yang digunakan dalam tahap ini adalah program komputer SPSS versi 17.

Seperti yang telah dijelaskan sebelumnya bahwa data utama yang diamati dalam penelitian ini merupakan data yang berasal dari knowledge network, yakni jejaring yang terdapat pertukaran informasi/pengetahuan di dalamnya. Unsur yang akan diteliti adalah relasi/interaksi antar aktor di dalam jejaring tersebut. Sumber data dari penelitian ini adalah Forum Kaskus, sebuah forum komunitas online, di mana setiap member yang terdaftar di dalamnya dapat saling berinteraksi untuk mengadakan suatu pembahasan mengenai topik tertentu. Member dapat saling memulai suatu thread dengan mengirimkan pesan di 
dalamnya ataupun membalas pesan dari member lain yang sudah ada pada suatu thread.

Data mengenai relasi/interaksi di antara member tersebut akan dipetakan ke dalam bentuk visual, yang menggambarkan pola interaksi yang terjadi dalam forum tersebut berkaitan dengan interaksi pesan yang ada. Perangkat yang digunakan dalam tahap ini adalah program komputer NetDraw untuk memvisualisasikan matriks yang didapat pada tahap pengumpulan data.

Analisis dan pembahasan dalam penelitian ini menggunakan metode Social Network Analysis (SNA) dengan tujuan untuk mendapatkan gambaran mengenai pola interaksi yang terjadi dalam forum. Pada tahap ini, akan digunakan program komputer UCINET untuk menganalisis pola interaksi tersebut. Jenis analisis SNA yang akan digunakan dalam penelitian ini, antara lain, analisis kepadatan jejaring secara keseluruhan, analisis komponen, analisis individual aktor, analisis perantara (brokerage). Analisis kepadatan jejaring secara keseluruhan bertujuan untuk menghitung ukuran jejaring atau dalam kata lain tingkat kepadatan/kerapatan dari jejaring forum yang diamati. Ukuran-ukuran yang digunakan dalam analisis ini adalah jumlah aktor atau node dari jejaring, kepadatan jejaring (density) dan derajat rata-rata (average degree) dari semua aktor atau node untuk mengukur kekuatan struktur dari jejaring. Analisis komponen bertujuan untuk memeriksa apakah suatu jejaring masih terbagi menjadi bagian-bagian (sub group) lagi atau tidak. Analisis individual aktor bertujuan untuk mengidentifikasi aktor yang paling sentral atau memiliki pengaruh yang besar dalam sebuah jejaring. Ukuran-ukuran yang digunakan dalam analisis ini adalah sentralitas derajat (degree centrality) baik derajat masuk maupun derajat keluar, sentralitas kedekatan (closeness centrality) dan sentralitas perantaraan (betweenness centrality). Analisis perantara (brokerage) bertujuan untuk mengidentifikasi aktor yang menempati posisi strategis dalam penyebaran atau aliran knowledge (aktor yang berperan sebagai penghubung bagi aktor/grup lainnya yang tidak saling terhubung sebelumnya). Ukuran yang diamati dalam analisis ini adalah cut point.

Kaskus adalah situs forum komunitas online terbesar Indonesia saat ini. Informasi dari situsnya, www.kaskus.us, 2009, Forum Kaskus lahir pada tanggal 6 November 2000 oleh tiga pemuda asal Indonesia yang sedang melanjutkan studi di Seattle, Amerika Serikat, yang bernama Andrew Darwis, Ronald Stephanus dan Budi Dharmawan. Namun selama dua tahun menjalankan forum ini, tampaknya belum menampakkan keuntungan secara bisnis, tidak ada iklan yang masuk, akhirnya kedua temannya hengkang sedangkan Andrew bertahan untuk melanjutkan sendiri forum yang telah dirintisnya ini dan bertekad untuk membesarkan Kaskus. Pertengahan tahun 2008, sepupunya Ken Dean Lawadinata meyakinkan Andrew untuk pulang ke Indonesia dan serius membesarkan Kaskus. Bersama seorang teman lain yang bernama Danny Wirianto, akhirnya mereka menjadi tiga orang penting di balik Kaskus di bawah bendera PT. Data Media Indonesia. Andrew tetap sebagai Admin dan berkonsentrasi pada pengembangan Kaskus, Ken sebagai CEO Kaskus yang bertanggung jawab pada manajemen perusahaan dan Danny bertanggung jawab sebagai CMO (Chief Marketing Officer).

Asal kata Kaskus sendiri dari kata kasak dan kusuk. Tujuan awal dari didirikannya komunitas ini adalah untuk menyatukan masyarakat online dalam dan luar negeri dalam satu komunitas. Kaskus selalu berusaha memberikan kebebasan berbicara dan berpikir bagi anggota karena Kaskus menganut asas freedom of speech merupakan salah satu dasar human rights seperti yang tercantum pada general rules pada situs (www.kaskus.us, 2009).

Manajemen situs kaskus dipimpin seorang administrator (admin) dan dua wakilnya, yaitu coadmin dan sleepy admin, serta dibantu oleh beberapa moderator. Moderator dipilih dari member Kaskus yang aktif di dalam forum tersebut. Moderator memiliki hak yang berbeda dari member biasa. Tugas seorang moderator adalah menjaga dan mengatur forum agar tertib, seperti mengawasi apakah thread pada forum atau sub forum berada pada tempat yang sesuai. Moderator memiliki hak untuk menghapus thread, mengunci (lock) thread, membuat status thread tersebut berada pada posisi sticky (berada pada top list pada halaman pertama sub forum) dan bahkan mem-banned member yang melanggar peraturan yang tercantum dalam situs Kaskus (general rule).

Forum Kaskus memiliki struktur yang bercabang (threaded), di mana forum terbagi ke dalam beberapa sub forum dengan topik bahasan yang paling umum, lalu setiap sub forum terbagi lagi menjadi topik-topik bahasan yang lebih kecil yang disebut threads. Pada beberapa threads, terdapat lagi pembagian menjadi satu atau lebih sub threads dengan topik yang lebih khusus. Threads/sub threads dibagi lagi menjadi threadthread dengan topik bahasan yang lebih fokus dan ditentukan sendiri oleh pengirim pesan pertama (thread starter). Bagian terkecil dari thread di Forum Kaskus adalah pesan-pesan yang dikirim oleh member sebagai tanggapan atau balasan terhadap thread tertentu. 
Pengguna Forum Kaskus umumnya berasal dari kalangan remaja hingga orang dewasa. Pembagian jenis pengguna yang ada di Forum Kaskus yaitu admin/administrator adalah orang yang bertugas untuk mengurusi hal-hal administrasi, mod/moderator adalah orang kepercayaan administrator untuk menjaga forum, donatur adalah member Forum Kaskus yang melakukan donasi ke Kaskus, dan member umum.

Dalam Forum Kaskus terdapat klasifikasi atau pengelompokan member umum berdasarkan jumlah pesan yang pernah dikirim oleh member tersebut di seluruh bagian Forum Kaskus. Dasar pembagian tersebut dapat dilihat pada tabel I.

TABEL I

KLASIFIKASI MEMBER BERDASARKAN JUMLAH PESAN (WWW.KASKUS.US, 2009)

\begin{tabular}{clc}
\hline \multicolumn{2}{c}{ (WwW.KASKUS.US, 2009) } \\
No & Klasifikasi member & $\begin{array}{c}\text { Jumlah pesan yang } \\
\text { dikirim }\end{array}$ \\
\hline 1 & Made in Kaskus & 50,000 atau lebih \\
2 & Kaskus Freak & $25,000-49,999$ \\
3 & Kaskus Geek & $10,000-24,999$ \\
4 & Kaskus Maniac & $4,000-9,999$ \\
5 & Kaskus Addict & $1,000-3,999$ \\
6 & Kaskus Holic & $750-999$ \\
7 & Aktivis Kaskus & $500-749$ \\
8 & Kaskuser & $100-499$ \\
9 & Newbie & $0-99$ \\
\hline \hline
\end{tabular}

Setiap member yang baru mendaftar dalam Forum Kaskus, otomatis akan diklasifikasikan menjadi seorang Newbie. Menurut Alexa.com, Kaskus berada di peringkat ke-370 situs di dunia (November 2009), dibandingkan berada di peringkat ke-1,229 situs dunia pada tahun 2007 dan menduduki peringkat ke delapan untuk urutan situs tersibuk di Indonesia. Saat ini member Kaskus (status pada November 2009) sudah mencapai lebih dari 1.2 juta akun dan terdapat sekitar 100 juta pesan di dalamnya. Kaskus juga sedang menambah kategori forum dan sub forumnya, seperti sub forum surat pembaca dengan harapan pengunjung situs semakin banyak.

\section{Hasil dan Pembahasan}

Penelitian ini dilakukan berdasarkan pengamatan/observasi langsung ke situs Forum Kaskus dengan mencatat dan menganalisis data mengenai interaksi yang terjadi pada forum tersebut melalui pesan yang di-post oleh masingmasing member forum tersebut. Seperti dalam sebuah forum online pada umumnya, setiap komunikasi dan pembahasan dilakukan pada masing-masing thread dengan bahasan-bahasan pada topik tertentu yang diatur di dalam sub forumnya. Setiap thread memiliki pembuka thread (thread starter) masing-masing, dan memungkinkan untuk semua member dalam forum tersebut untuk membalasnya dengan pesanpesan yang tentunya juga diharapkan memiliki hubungan dengan topik bahasan.

Pengamatan yang dilakukan dalam penelitian ini adalah dengan mencatat setiap interaksi maupun hubungan yang terjadi dalam Forum Kaskus Sub Forum Computer Stuff Thread Programmer Forum ke dalam sebuah matriks yang menyimpan nama-nama member yang aktif selama kurun waktu yang ditetapkan dan juga interaksi yang terjadi antar member tersebut.

Matriks ketetanggaan (adjacency matrix) terdiri dari banyaknya seorang peserta yang ada di baris yang bersesuaian mengirim pesan balasan kepada peserta yang ada di kolom yang bersesuaian. Hal yang dicatat banyaknya interaksi yang terjadi ke dalam setiap sel dari matriks tersebut.

Matriks itu disebut matriks ketetanggaan (adjacency). Angka-angka yang tertera di dalam setiap sel pada matriks tersebut dapat dipahami sebagai berikut: angka yang ada di baris i dan kolom $\mathrm{j}$ menggambarkan banyaknya pesan balasan yang diberikan oleh peserta di dalam baris $\mathrm{i}$ tersebut kepada peserta yang ada di kolom $\mathrm{j}$. Dalam penelitian ini, yang diteliti adalah relasi yang terjadi di antara member, maka dari itu nilai pada diagonal matriks yang menyatakan banyaknya pesan balasan yang dikirimkan oleh member tersebut terhadap thread yang dibuatnya akan dihapus dan dianggap bernilai 0 .

Pada Forum Kaskus, member diidentifikasi dengan menggunakan nick name atau member ID, namun dalam penelitian ini, akan digunakan hanya member ID saja, yaitu berupa angka unik yang merujuk ke masing-masing member. Terdapat 535 member yang ikut berinteraksi melalui pesan dalam kurun waktu tersebut, termasuk di dalamnya empat orang moderator Thread Programmer Forum yaitu dengan ID member: 4813, 52451, 345040 dan 241399.

Jumlah keseluruhan pesan yang diteliti dalam penelitian ini adalah sebanyak 1182 pesan (termasuk di dalamnya 365 pesan yang dikirim ke diri sendiri), yang merupakan jumlah pesan/posting yang dilakukan oleh member forum Sub Forum Computer Stuff - Thread Programmer Forum yang tertanggal di bulan Mei 2009. Semua pesan tersebut diatur secara terstruktur di dalam 306 thread yang diamati dalam penelitian ini.

Data statistik yang dikumpulkan terdiri dari data mengenai member dan thread. Data tersebut akan dilakukan analisis awal untuk mengetahui 
ukuran statistik mengenai data member dan thread di forum yang sedang diamati.

Pada tabel II disajikan data member berdasarkan klasifikasinya, menyajikan informasi mengenai member yang aktif dalam interaksi di forum dan dikelompokkan berdasarkan klasifikasi member yang ada di Forum Kaskus. Hal ini untuk mendapat gambaran, klasifikasi member mana yang lebih aktif di dalam forum Thread Programmer Forum selama bulan Mei 2009.

Dari tabel tersebut dapat dilihat, bahwa golongan 'Kaskus addict' menempati posisi teratas dengan jumlah 149 member. 'Kaskus addict' adalah golongan member di Forum Kaskus yang telah mengirim antara 1000 s.d. 3999 pesan. Sedangkan di posisi kedua ada golongan Newbie dengan jumlah 132 member. Newbie adalah golongan member yang telah mengirim antara 0 s.d. 99 pesan.

Sedangkan di urutan ketiga ada golongan 'Kaskuser' dengan jumlah 127 member, yaitu golongan member di Forum Kaskus yang telah mengirim 100 s.d. 499 pesan. Dari data tersebut, dapat disimpulkan bahwa selama bulan Mei 2009, jumlah member dengan jumlah posting menengah ke bawah lebih banyak aktif di Thread Programmer Forum dibandingkan dengan jumlah member dengan jumlah postingan menengah ke atas.

Gambar 1 menyajikan beberapa gambar visualisasi jejaring yang dibentuk berdasarkan interaksi yang terjadi di forum tersebut dan ditampilkan melalui beberapa kategori tampilan. Gambar tersebut dibuat dengan bantuan program komputer NetDraw yang terintegrasi dengan program komputer UCINET.

TABEL II

DATA MEMBER BERDASARKAN KLASIFIKASINYA

\begin{tabular}{lcccc}
\hline $\begin{array}{l}\text { Klasifikasi } \\
\text { member }\end{array}$ & Frekuensi & $\begin{array}{c}\text { Persenta } \\
\text { se }(\%)\end{array}$ & $\begin{array}{c}\text { Persenta } \\
\text { se valid } \\
(\%)\end{array}$ & $\begin{array}{c}\text { Persen } \\
\text { tase } \\
\text { kumul } \\
\text { atif }\end{array}$ \\
\hline $\begin{array}{l}\text { Kaskus } \\
\text { addict }\end{array}$ & 149 & 27,9 & 27,9 & 27,9 \\
$\begin{array}{l}\text { Newbie } \\
\text { Kaskuser }\end{array}$ & 132 & 24,7 & 24,7 & 52,5 \\
$\begin{array}{l}\text { Aktivis } \\
\text { Kaskus }\end{array}$ & 127 & 23,7 & 23,7 & 76,3 \\
$\begin{array}{l}\text { Kaskus } \\
\text { holic }\end{array}$ & 35 & 6,9 & 6,9 & 83,2 \\
$\begin{array}{l}\text { Kaskus } \\
\text { maniac }\end{array}$ & 25 & 6,5 & 6,5 & 89,7 \\
$\begin{array}{l}\text { Kaskus } \\
\text { Donator }\end{array}$ & 13 & 4,7 & 4,7 & 94,4 \\
$\begin{array}{l}\text { Auto } \\
\text { Banned }\end{array}$ & 6 & 2,4 & 2,4 & 96,8 \\
kaskus \\
geek \\
$\begin{array}{l}\text { Moderator } \\
\text { Kaskus }\end{array}$ & 6 & 1,1 & 1,1 & 97,9 \\
\hline \multicolumn{1}{c}{ Total } & 535 & 100,0 & 100,0 & \\
\hline \hline & & & & \\
\hline
\end{tabular}

TABEL III

SEBARAN DATA THREAD BERDASARKAN THREAD STARTER

\begin{tabular}{cccc}
\hline $\begin{array}{c}\text { Kelas } \\
\text { frekuensi }\end{array}$ & $\begin{array}{c}\text { Jumlah } \\
\text { member }\end{array}$ & Frekuensi & $\begin{array}{c}\text { Persentase } \\
\text { frekuensi } \\
(\%)\end{array}$ \\
\hline 6 & 2 & 12 & 3,92 \\
5 & 1 & 5 & 1,63 \\
4 & 1 & 4 & 1,31 \\
3 & 5 & 15 & 4,90 \\
2 & 31 & 62 & 20,26 \\
1 & 208 & 208 & 67,97 \\
& & & \\
\hline Jumlah & 248 & 306 & 100,00 \\
& & & \\
\hline \hline
\end{tabular}

Tabel III menyajikan data thread berdasarkan member yang memulainya (yang mengirimkan pesan pertama dalam diskusi tersebut). Dari data tersebut diketahui bahwa dari 306 thread yang diamati dalam penelitian ini, berasal dari 248 member yang berbeda-beda sebagai thread starter. Di mana member terbanyak sebagai thread starter ada dua orang dengan frekuensi masing-masing enam kali, sedangkan sekitar 208 member lainnya hanya menjadi thread starter sebanyak satu kali. Hal ini menandakan bahwa selama bulan Mei 2009, member yang membuat thread baru pada Thread Programmer Forum lebih bervariasi, hal ini dapat memengaruhi topik bahasan yang diajukan member tersebut, sehingga lebih bervariasi juga.

Jejaring yang dihasilkan adalah jejaring berarah (directed network), jejaring yang di dalamnya sebuah aktor/node dapat memiliki hubungan berarah dengan aktor/node dalam jejaring tersebut. Aktor/node diberi label ID member-nya masing-masing.

Visualisasi jejaring secara keseluruhan yang terdiri dari 535 aktor dan memiliki 598 ikatan/tie yang menghubungkan aktor-aktor tersebut, namun dalam jejaring tersebut masih terdapat 56 aktor yang tidak terhubung sama sekali dengan aktor lainnya dalam jejaring tersebut. Pada gambar 1 disajikan mengenai visualisasi seluruh jejaring dengan memberi tanda dengan warna node mana yang merupakan aktor terisolasi dan mana yang tidak.

Pemetaan pola interaksi juga dilakukan berdasarkan klasifikasi dari member di Forum Kaskus, yang terdiri dari sembilan jenis member. Namun jika dipisahkan berdasarkan klasifikasi member tersebut, hanya pada lima klasifikasi member terdapat hubungan/ikatan/tie pada jejaringnya, yakni pada klasifikasi member: Kaskus Maniac, Kaskuser, Aktivis Kaskus, Kaskus Addict, dan Newbie. 


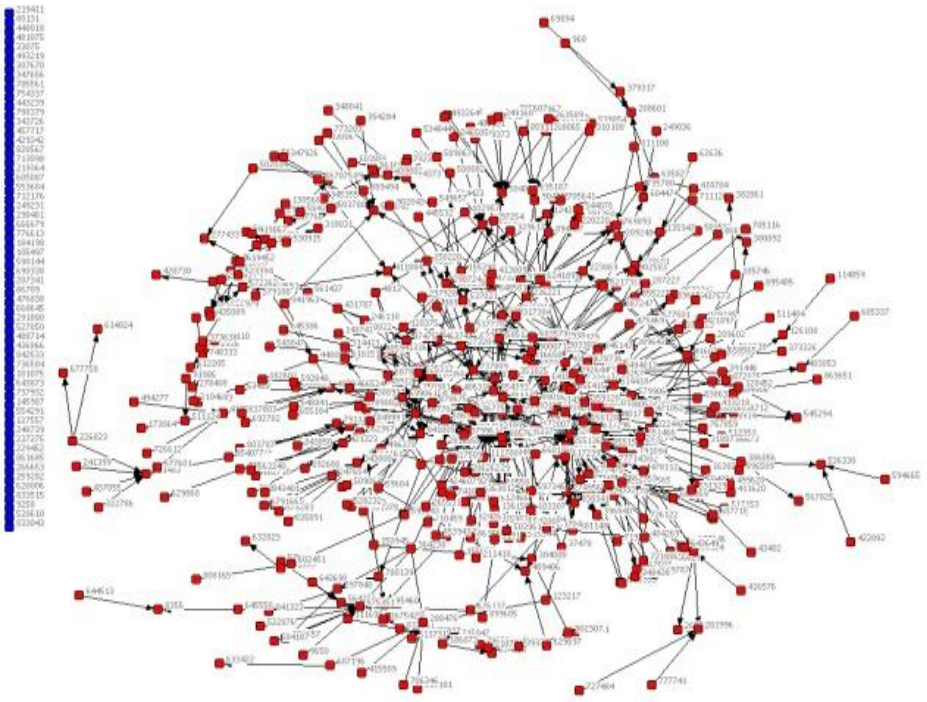

Gambar 1. Visualisasi jejaring.

Tujuan visualisasi ini hanya untuk menunjukkan ternyata antar klasifikasi member tidak pada semua klasifikasi mempunyai hubungan di antara member yang termasuk di dalamnya, misalnya pada klasifikasi member: Kaskus Freak, Kaskus Geek, dan Kaskus Holic tidak saling terhubung di antara member yang termasuk di dalam klasifikasinya. Analisis ini bertujuan untuk mengetahui keadaan jejaring secara keseluruhan berdasarkan jumlah aktor dan kepadatan relasi antar aktor tersebut. Jumlah member yang diamati dalam penelitian ini adalah sebanyak 535 member. Jadi besar dari jejaring ini adalah 535 .

Jenis interaksi yang terjadi di forum ini merupakan jenis jejaring yang asimetris di mana pasangan unik yang terjadi dari baris ke kolom tidak sama dengan pasangan unik dari kolom ke baris yang sama. Untuk itu jumlah pasangan unik yang mungkin terjadi dan derajat aktor atau batasan jumlah hubungan adalah sebagai berikut:

$$
\begin{aligned}
\text { Jumlah pasangan unik } & =\mathrm{n} \times(\mathrm{n}-1) \\
& =535 \times 534 \\
& =285.690
\end{aligned}
$$

Derajat aktor

$$
\begin{aligned}
& =\mathrm{n}-1 \\
& =535-1 \\
& =534
\end{aligned}
$$

Kepadatan sebuah jejaring dapat memberitahu tentang bagaimana informasi bergerak antara titik-titik dalam jejaring tersebut dan juga aktor mana yang memiliki modal sosial yang tinggi. Tabel IV adalah perhitungan dengan program UCINET:
TABEL IV

Nilai Derajat Rata-Rata DENGan Matriks VALUED

\begin{tabular}{cc}
\hline \hline Avg Value & Std Dev \\
\hline 1,3662 & 1,0368
\end{tabular}

Angka tersebut menunjukkan bahwa ratarata setiap member dalam forum tersebut membuat 1.3662 posting-an dengan simpangan baku 1.0368. Sedangkan jika dilakukan perhitungan dengan menggunakan matriks dikotomik maka akan didapat nilai kepadatan sebesar 0.0021 dengan jumlah ikatan sebanyak 598.

Nilai kepadatan tersebut menggambarkan bahwa jejaring yang diamati bukanlah termasuk jejaring yang lengkap (nilai kepadatan jaringan lengkap $=1$ ). Kepadatan sebuah jejaring menggambarkan mengenai seberapa cepat penyebaran pengetahuan di antara aktor di dalamnya. Hal ini menunjukkan bahwa sebagian besar member dalam forum ini masih jarang memberikan informasi, mengajukan pertanyaan maupun menjawab pertanyaan.

Nilai kepadatan jejaring sebenarnya kurang tepat dalam menilai keeratan hubungan antar aktornya karena nilai kepadatan jejaring hanya bergantung pada ukuran jejaring, padahal kepadatan jejaring berbanding terbalik dengan ukurannya. Kepadatan suatu jejaring akan lebih tepat jika dilihat dari jumlah relasi/hubungan antar aktor yang terdapat di dalam jejaring tersebut, yang disebut dengan istilah derajat (degree).

Aktor dengan derajat yang tinggi lebih mungkin ditemukan pada jejaring yang kepadatannya juga tinggi. Derajat aktor yang tinggi akan menghasilkan jejaring yang lebih 
padat karena terbentuknya lebih banyak hubungan di dalam jejaring tersebut.

Pada tabel V disajikan tabel sentralitas derajat dari Forum Kaskus Sub Forum Computer Stuff - Thread Programmer Forum. Tabel V didapat dari pengolahan terhadap hasil analisis dengan bantuan program UCINET untuk menghitung sentralitas derajat dari jejaring di Forum Kaskus. Tabel tersebut menyajikan frekuensi distribusi sentralitas derajat masingmasing aktor dalam jejaring tersebut.

Kolom paling kiri, yakni kolom Kelompok Derajat menunjukkan sebaran nilai derajat dari yang terendah hingga yang tertinggi dalam jejaring tersebut. Kolom frekuensi menunjukkan banyaknya aktor atau member yang memiliki nilai derajat tertentu. Kolom persentase frekuensi menunjukkan persentase frekuensi tertentu dibandingkan dengan total frekuensi. Sedangkan kolom paling kanan, yakni Perwakilan Kelompok menunjukkan ID member yang mewakili kelompok tertentu dalam sebaran frekuensi sentralitas derajat tersebut.

TABEL V

DISTRIBUSI FREKUENSI SENTRALITAS DERAJAT DALAM JEJARING

\begin{tabular}{|c|c|c|c|}
\hline $\begin{array}{c}\text { Kelompok } \\
\text { derajat }\end{array}$ & Frekuensi & $\begin{array}{c}\text { Persentase } \\
\text { frekuensi }(\%)\end{array}$ & $\begin{array}{l}\text { Perwakilan } \\
\text { kelompok } \\
\text { (ID } \\
\text { member) }\end{array}$ \\
\hline 0 & 56 & 10.47 & 488714 \\
\hline 1 & 242 & 45.23 & 705641 \\
\hline 2 & 75 & 14.02 & 602451 \\
\hline 3 & 44 & 8.22 & 840177 \\
\hline 4 & 39 & 7.29 & 406316 \\
\hline 5 & 16 & 2.99 & 150945 \\
\hline 6 & 16 & 2.99 & 288476 \\
\hline 7 & 7 & 1.31 & 547048 \\
\hline 8 & 9 & 1.68 & 683579 \\
\hline 9 & 9 & 1.68 & 314418 \\
\hline 10 & 4 & 0.75 & 435056 \\
\hline 11 & 2 & 0.37 & 873109 \\
\hline 12 & 2 & 0.37 & 737809 \\
\hline 13 & 2 & 0.37 & 347890 \\
\hline 14 & 1 & 0.19 & 255136 \\
\hline 15 & 1 & 0.19 & 501379 \\
\hline 16 & 1 & 0.19 & 439565 \\
\hline 18 & 2 & 0.37 & 624189 \\
\hline 22 & 1 & 0.19 & 805767 \\
\hline 26 & 1 & 0.19 & 854393 \\
\hline 35 & 1 & 0.19 & 118866 \\
\hline 39 & 1 & 0.19 & 132189 \\
\hline 64 & 1 & 0.19 & 558778 \\
\hline 76 & 1 & 0.19 & 52451 \\
\hline 117 & 1 & 0.19 & 529143 \\
\hline Jumlah & 535 & 100.00 & \\
\hline
\end{tabular}

Dari tabel di atas, didapat bahwa member dengan ID 529143 memiliki jumlah hubungan terbanyak dalam jejaring tersebut, sedangkan salah satu member yang terisolasi (dari 56 member) dalam jejaring tersebut adalah member dengan perwakilan ID 488714, dengan jumlah hubungan 0 , atau tidak terhubung dengan member lainnya.

Tabel VI menyajikan perhitungan statistik deskriptif terhadap nilai sentralitas derajat jejaring tersebut. Didapat nilai rata-rata dari jumlah hubungan yang terjadi di dalam jejaring tersebut adalah 3.047 dengan simpangan baku 7.398.

TABEL VI

STATISTIK DESKRIPTIF DARI SENTRALITAS DERAJAT

\begin{tabular}{cc}
\hline \hline Statistik deskriptif & Derajat \\
\hline Nilai rata-rata & 3.047 \\
Simpangan baku & 7.398 \\
Jumlah & 1630 \\
Minimum & 0 \\
Maximum & 117 \\
\hline Sentralisasi jejaring & $2.14 \%$ \\
\hline \hline
\end{tabular}

Analisis ini bertujuan untuk memeriksa apakah suatu jejaring masih terbagi menjadi bagian-bagian (sub group) lagi atau tidak. Pada tabel di bawah ini, disajikan data mengenai jumlah komponen (sub group) yang bisa dibentuk dari jejaring forum yang diamati. Hal ini berarti, jejaring itu dapat dibagi-bagi lagi menjadi beberapa bagian yang lebih kecil. Pembagian tersebut dengan memperhatikan keterikatan antara aktor dalam jejaring tersebut dan juga arah dari hubungan yang ada.

TABEL VII

JUMLAH KOMPONEN PADA JEJARING

\begin{tabular}{|c|c|c|c|c|}
\hline \multirow[t]{2}{*}{ Jejaring } & \multicolumn{2}{|c|}{$\begin{array}{c}\text { Jumlah komponen kuat } \\
\text { (strong component) }\end{array}$} & \multicolumn{2}{|c|}{$\begin{array}{c}\text { Jumlah } \\
\text { komponen } \\
\text { lemah (weak } \\
\text { component) }\end{array}$} \\
\hline & $\begin{array}{c}\text { Jumlah } \\
\text { node per } \\
\text { komponen }\end{array}$ & $\begin{array}{l}\text { Jumlah } \\
\text { kompo } \\
\text { nen }\end{array}$ & $\begin{array}{c}\text { Jumlah } \\
\text { node } \\
\text { per } \\
\text { kompo } \\
\text { nen }\end{array}$ & $\begin{array}{c}\text { Jumlah } \\
\text { kompo } \\
\text { nen }\end{array}$ \\
\hline \multirow{6}{*}{$\begin{array}{c}\text { Thread } \\
\text { Progra } \\
\text { mmer } \\
\text { Forum }\end{array}$} & 1 & 531 & 1 & 56 \\
\hline & & & 2 & 17 \\
\hline & & & 3 & 4 \\
\hline & 2 & 2 & 4 & 2 \\
\hline & & & 12 & 1 \\
\hline & & & 413 & 1 \\
\hline
\end{tabular}

Dari tabel VII, dapat diketahui bahwa komponen kuat (strong component) yang terdiri dari 531 komponen dengan jumlah node per komponen adalah 1, dan 2 komponen dengan jumlah node per komponen adalah 2. Komponen yang memiliki dua node adalah komponen di mana node-node yang tergabung di dalamnya saling terhubung dengan path dengan mengindahkan arah dari hubungan, sedangkan 531 komponen lainnya adalah komponen- 
komponen di mana node yang terdapat di dalamnya merupakan node yang terisolasi atau bisa terhubung dengan yang lain tetapi tanpa mengindahkan arah dari hubungan (semi path).

Sedangkan untuk komponen lemah (weak component) terdiri dari 56 komponen dengan jumlah node per komponen adalah 1, 17 komponen dengan jumlah node per komponen adalah 2, 4 komponen dengan jumlah node per komponen adalah 3, 2 komponen dengan jumlah node per komponen adalah 4, 1 komponen dengan jumlah node per komponen adalah 12, dan 1 komponen dengan jumlah node per komponen adalah 413 .

Analisis ini bertujuan untuk mengidentifikasi aktor yang paling sentral atau memiliki pengaruh yang besar dalam sebuah jejaring. Ukuran-ukuran yang digunakan dalam analisis ini adalah sentralitas derajat (degree centrality) baik derajat masuk maupun derajat keluar, sentralitas kedekatan (closeness centrality) dan sentralitas perantaraan (betweenness centrality).

Dari tabel VIII tentang 20 Besar Sentralitas Out-Degree, diketahui bahwa member dengan ID 529143 mempunyai derajat keluar yang paling tinggi, disusul dengan member dengan ID 52451 dan 558778. Nilai derajat keluar di sini berkaitan dengan pola interaksi yang terjadi di dalam forum, yakni derajat keluar menggambarkan bahwa seorang member melakukan pengiriman pesan kepada member lain, bisa saja pesan tersebut merupakan jawaban, informasi atau tanggapan. Dengan kata lain, member dengan ID 529143, 52451 dan 558778 adalah member yang paling banyak melakukan pengiriman pesan kepada member lain.

TABEL VIII

\begin{tabular}{|c|c|c|}
\hline Peringkat & ID member & $\begin{array}{c}\text { Out- } \\
\text { degree }\end{array}$ \\
\hline 1 & 529143 & 117 \\
\hline 2 & 52451 & 71 \\
\hline 3 & 558778 & 64 \\
\hline 4 & 624189 & 18 \\
\hline 5 & 364931 & 14 \\
\hline 6 & 273204 & 12 \\
\hline 7 & 873109 & 11 \\
\hline 8 & 501379 & 10 \\
\hline 9 & 155290 & 9 \\
\hline 10 & 307096 & 9 \\
\hline 11 & 364238 & 9 \\
\hline 12 & 537929 & 7 \\
\hline 13 & 635827 & 6 \\
\hline 14 & 348051 & 6 \\
\hline 15 & 274956 & 6 \\
\hline 16 & 737809 & 6 \\
\hline 17 & 586358 & 6 \\
\hline 18 & 236221 & 6 \\
\hline 19 & 56019 & 6 \\
\hline 20 & 150945 & 5 \\
\hline
\end{tabular}

TABEL IX

DistRIBUSI FREKUENSI SENTRALITAS OUT-DEGREE

\begin{tabular}{ccc}
\hline \hline Kelompok Out-degree & Frekuensi & $\begin{array}{c}\text { Persentase } \\
\text { frekuensi }(\%)\end{array}$ \\
\hline 117 & 1 & 0.19 \\
71 & 1 & 0.19 \\
64 & 1 & 0.19 \\
18 & 1 & 0.19 \\
14 & 1 & 0.19 \\
12 & 1 & 0.19 \\
11 & 1 & 0.19 \\
10 & 1 & 0.19 \\
9 & 3 & 0.56 \\
7 & 1 & 0.19 \\
6 & 7 & 1.31 \\
5 & 5 & 0.93 \\
4 & 17 & 3.18 \\
3 & 20 & 3.74 \\
2 & 36 & 6.73 \\
1 & 199 & 37.20 \\
0 & 239 & 44.67 \\
\hline Jumlah & 535 & 100.00 \\
\hline \hline
\end{tabular}

Tabel IX tentang Distribusi Frekuensi Sentralitas Out-Degree, menyajikan sebaran nilai sentralitas out-degree dari masing-masing member di dalam forum. Dari tabel tersebut dapat disimpulkan bahwa hanya sebagian kecil dari member forum tersebut yang aktif dalam memberikan pesan balasan kepada member lainnya, bahkan sekitar $44.67 \%$ dari jumlah member sama sekali tidak pernah memberikan pesan balasan kepada member lainnya.

TABEL $X$

STATISTIK DESKRIPTIF DARI SENTRALITAS OUT-DEGREE

\begin{tabular}{lc}
\hline \hline Statistik deskriptif & Derajat \\
\hline Nilai rata-rata & 1.527 \\
Simpangan baku & 6.688 \\
Jumlah & 817 \\
Minimum & 0 \\
Maximum & 117 \\
\hline Sentralisasi jejaring & $2.166 \%$ \\
\hline \hline
\end{tabular}

Tabel $\mathrm{X}$ menyajikan perhitungan statistik deskriptif terhadap nilai Sentralitas Out-Degree jejaring tersebut. Didapat nilai rata-rata dari jumlah hubungan yang keluar dari aktor di dalam jejaring tersebut adalah 1.527 dengan simpangan baku 6.688

Dari tabel XI tentang 20 Besar Sentralitas InDegree, diketahui bahwa member dengan ID 132189 mempunyai derajat masuk yang paling tinggi, disusul dengan member dengan ID 118866 dan 854393. Nilai derajat masuk di sini berkaitan dengan pola interaksi yang terjadi di dalam forum, yakni derajat masuk menggambarkan bahwa seorang member mendapat balasan pesan dari member lain, bisa saja pesan tersebut merupakan jawaban, informasi atau tanggapan. Dengan kata lain, member dengan ID 132189, 118866, dan 854393 adalah member yang paling banyak mendapatkan pesan balasan dari member lain. 
Tabel XII tentang Distribusi Frekuensi Sentralitas In-Degree, menyajikan sebaran nilai sentralitas In-Degree dari masing-masing member di dalam forum. Dari tabel tersebut dapat disimpulkan bahwa hanya sebagian kecil dari member forum tersebut yang sering mendapatkan pesan balasan dari member lainnya, bahkan sekitar $60.56 \%$ dari jumlah member sama sekali tidak pernah mendapatkan pesan balasan dari member lainnya.

TABEL XI

DAFTAR 20 BESAR

\begin{tabular}{ccc}
\hline & DAFTAR 20 BESAR & \\
\hline \hline Peringkat & ID member & In-degree \\
\hline 1 & 132189 & 38 \\
3 & 118866 & 26 \\
4 & 854393 & 22 \\
5 & 805767 & 16 \\
6 & 439565 & 14 \\
7 & 255136 & 13 \\
8 & 347890 & 13 \\
9 & 841009 & 11 \\
10 & 575351 & 10 \\
11 & 435056 & 10 \\
12 & 852087 & 10 \\
13 & 111700 & 9 \\
14 & 504098 & 9 \\
15 & 314418 & 9 \\
16 & 351134 & 9 \\
17 & 459704 & 9 \\
18 & 655380 & 9 \\
19 & 494813 & 9 \\
20 & 351825 & 8 \\
\hline \hline
\end{tabular}

TABEL XII

DISTRIBUSI FREKUENSI SENTRALITAS IN-DEGREE

\begin{tabular}{ccc}
\hline $\begin{array}{c}\text { Kelompok In- } \\
\text { degree }\end{array}$ & Frekuensi & $\begin{array}{c}\text { Persentase } \\
\text { frekuensi }(\%)\end{array}$ \\
\hline 38 & 1 & 0.19 \\
35 & 1 & 0.19 \\
26 & 1 & 0.19 \\
22 & 1 & 0.19 \\
16 & 1 & 0.19 \\
14 & 1 & 0.19 \\
13 & 2 & 0.37 \\
11 & 1 & 0.19 \\
10 & 3 & 0.56 \\
9 & 7 & 1.31 \\
8 & 7 & 1.31 \\
7 & 5 & 0.93 \\
6 & 9 & 1.68 \\
5 & 15 & 2.80 \\
4 & 20 & 3.74 \\
3 & 28 & 5.23 \\
2 & 44 & 8.22 \\
1 & 64 & 11.96 \\
0 & 324 & 60.56 \\
\hline Jumlah & 535 & 100.00 \\
\hline \hline
\end{tabular}

TABEL XIII

STATISTIK DESKRIPTIF DARI SENTRALITAS IN-DEGREE

\begin{tabular}{lc}
\hline \hline \multicolumn{1}{c}{ Statistik deskriptif } & Derajat \\
\hline Nilai rata-rata & 1.527 \\
Simpangan baku & 3.503 \\
Jumlah & 817 \\
Minimum & 0 \\
Maximum & 38 \\
\hline Sentralisasi jejaring & $0.684 \%$ \\
\hline \hline
\end{tabular}

Tabel XIII menyajikan perhitungan statistik deskriptif terhadap nilai Sentralitas In-Degree jejaring tersebut. Didapat nilai rata-rata dari jumlah hubungan yang masuk ke dalam aktor di dalam jejaring tersebut adalah 1.527 dengan simpangan baku 3.503. Analisis terhadap sentralitas kedekatan dilatarbelakangi oleh ide bahwa suatu aktor dapat mencapai aktor lainnya dengan jalan/path yang lebih pendek atau suatu aktor dapat dicapai oleh aktor lainnya dengan jalan/ path yang lebih pendek.

Dari tabel XIV di bawah, diketahui bahwa member dengan ID 529143 memiliki nilai sentralitas kedekatan tertinggi dalam jejaring tersebut, hal ini berarti bahwa member tersebut memiliki jalan/path paling pendek untuk mencapai member lainnya dalam jejaring tersebut. Hal tersebut mengakibatkan bahwa member dengan ID 529143 lebih cepat dan mudah dalam berkomunikasi dengan member lainnya dalam jejaring tersebut tanpa melalui banyak perantara.

TABEL XIV

\begin{tabular}{ccc} 
DAFTAR 20 BESAR SENTRALITAS KEDEKATAN & Sentralitas \\
Peringkat & ID member & \\
& & 0.804084 \\
1 & 529143 & 0.803418 \\
2 & 52451 & 0.802742 \\
3 & 558778 & 0.802694 \\
4 & 132189 & 0.802091 \\
5 & 854393 & 0.80191 \\
6 & 805767 & 0.801898 \\
7 & 853399 & 0.801754 \\
8 & 654827 & 0.801441 \\
9 & 737809 & 0.801248 \\
10 & 379961 & 0.80102 \\
11 & 36775 & 0.800996 \\
12 & 435056 & 0.800984 \\
13 & 510370 & 0.80096 \\
14 & 537453 & 0.80084 \\
15 & 111700 & 0.800744 \\
16 & 364931 & 0.800708 \\
17 & 501379 & 0.800648 \\
18 & 118866 & 0.800456 \\
19 & 678736 & \\
20 & 351134 & \\
& & \\
\hline
\end{tabular}


TABEL XV

STATISTIK DESKRIPTIF DARI SENTRALITAS KEDEKATAN

\begin{tabular}{lr}
\hline \multicolumn{1}{c}{$\begin{array}{c}\text { Statistik } \\
\text { deskriptif }\end{array}$} & \multicolumn{1}{c}{ Deraja } \\
\hline Nilai rata-rata & 0.711 \\
Simpangan baku & 0.209 \\
Jumlah & 340.5 \\
Minimum & 80 \\
Maximum & 0.187 \\
\hline Sentralisasi & 0.804 \\
jejaring & \\
\hline \hline
\end{tabular}

Tabel XV menyajikan perhitungan statistik deskriptif terhadap nilai Sentralitas Kedekatan jejaring tersebut. Didapat nilai rata-rata dari sentralitas kedekatan di dalam jejaring tersebut adalah 0.711 dengan simpangan baku 0.209 . Analisis terhadap sentralitas perantara dilatarbelakangi oleh ide bahwa aktor yang posisinya berada di antara aktor lainnya membuat aktor tersebut menjadi berkuasa (poweful) karena dapat mengontrol aliran informasi, sumber daya, pengetahuan, atau hal lainnya.

Tabel XVII menyajikan perhitungan statistik deskriptif terhadap nilai Sentralitas Perantara jejaring tersebut. Didapat nilai rata-rata dari sentralitas perantara di dalam jejaring tersebut adalah 0 dengan simpangan baku 0.003 .

TABEL XVI

Daftar 20 Besar Sentralitas Perantara

\begin{tabular}{ccc}
\hline \hline Peringkat & ID member & $\begin{array}{c}\text { Sentralitas } \\
\text { perantara }\end{array}$ \\
\hline 1 & 52451 & 0.056742 \\
2 & 501379 & 0.032148 \\
3 & 364931 & 0.028459 \\
4 & 452148 & 0.013702 \\
5 & 132189 & 0.009838 \\
6 & 737809 & 0.008432 \\
7 & 118866 & 0.00773 \\
8 & 274956 & 0.006676 \\
9 & 416079 & 0.005621 \\
10 & 599061 & 0.00527 \\
11 & 251337 & 0.003513 \\
12 & 504098 & 0.002811 \\
13 & 412205 & 0.002108 \\
14 & 351134 & 0.002108 \\
15 & 678736 & 0.002108 \\
16 & 208712 & 0.001757 \\
17 & 448096 & 0.001054 \\
18 & 38124 & 0.001054 \\
19 & 579906 & 0.001054 \\
20 & 470599 & 0.000703 \\
\hline \hline
\end{tabular}

Dari tabel XVI di atas, diketahui bahwa member dengan ID 52451 memiliki nilai sentralitas perantara tertinggi dalam jejaring tersebut, hal ini berarti bahwa member tersebut merupakan aktor penghubung atau broker. Hal tersebut mengakibatkan bahwa member dengan ID 52451 adalah aktor yang berkuasa dalam jejaring tersebut, karena banyak aktor lain dalam jejaring tersebut bergantung kepadanya dalam membuat hubungan dalam jejaring tersebut.

Analisis ini bertujuan untuk mengidentifikasi aktor yang menempati posisi strategis dalam penyebaran/aliran knowledge (aktor yang berperan sebagai penghubung bagi aktor/grup lainnya yang tidak saling terhubung sebelumnya). Ukuran yang diamati dalam analisis ini adalah cut point.

TABEL XVII

STATISTIK DESKRIPTIF DARI SENTRALITAS PERANTARA

\begin{tabular}{lc}
\hline \hline \multicolumn{1}{c}{ Statistik deskriptif } & Derajat \\
\hline Nilai rata-rata & 0.000 \\
Simpangan baku & 0.003 \\
Jumlah & 0.197 \\
Minimum & 0.000 \\
Maximum & 0.057 \\
& \\
\hline Sentralisasi jejaring & $0.06 \%$ \\
\hline \hline
\end{tabular}

Cut point, yakni aktor-aktor yang jika dihapus dari suatu jejaring akan memecah jejaring tersebut menjadi bagian-bagian yang terpisah dan bagian-bagian tersebut disebut blok-blok yang merupakan bagian dengan jumlah node maksimum yang tidak bisa dipisahkan lagi. Untuk menemukan cut point dalam jejaring tersebut, digunakan program komputer UCINET dengan pendekatan Bi-Component.

Dari perhitungan menggunakan program UCINET didapat sebanyak 123 cut point dan 297 blok-blok. Tabel XVIII berikut merupakan hasil dari program komputer UCINET yang menyajikan cut point yang terdapat dalam jejaring tersebut. Cut point di bawah merupakan aktor yang penting dalam jejaring tersebut, karena aktor tersebut dapat berperan sebagai penghubung dari grup/kelompok lainnya yang tidak terhubung. Untuk gambar visualisasi dari jejaring tersebut dengan cut point membagi-bagikan menjadi blokblok dapat dilihat pada gambar 1 . 
TABEL XVIII

DAFTAR CUT POINT DALAM JEJARING

\begin{tabular}{cccc}
\hline \hline \multicolumn{4}{c}{ Member ID } \\
\hline 564258 & 654827 & 401717 & 316658 \\
52451 & 191894 & 635187 & 836657 \\
582178 & 347890 & 862353 & 750381 \\
558778 & 280837 & 854393 & 111700 \\
155290 & 351134 & 364931 & 428390 \\
635827 & 439312 & 416079 & 343800 \\
255136 & 228601 & 852087 & 777143 \\
412205 & 304080 & 218257 & 572362 \\
265579 & 617296 & 655380 & 769893 \\
439565 & 780139 & 561161 & 536501 \\
672817 & 649912 & 604906 & 599061 \\
470599 & 273204 & 579906 & 575351 \\
715047 & 91371 & 208601 & 645550 \\
494332 & 132189 & 604474 & 531329 \\
504098 & 172007 & 841009 & 158128 \\
501379 & 850979 & 52173 & 537021 \\
226823 & 853399 & 420875 & 805767 \\
9859 & 335006 & 624189 & 371653 \\
314418 & 791127 & 855227 & 678736 \\
529143 & 854077 & 421323 & 5191 \\
565529 & 321483 & 489406 & 126108 \\
114115 & 435115 & 873109 & 442969 \\
497039 & 38124 & 536330 & 403053 \\
379317 & 118866 & 386056 & 494813 \\
737809 & 496378 & 478112 & 551466 \\
544295 & 400757 & 222447 & 298724 \\
54651 & 537453 & 607196 & 411884 \\
448096 & 201996 & 288476 & 223869 \\
602451 & 562367 & 845147 & 135947 \\
504231 & 236221 & 36775 & 8356 \\
510370 & 484373 & 547048 & \\
\hline \hline & & & \\
5 & 539 \\
\hline
\end{tabular}

\section{Kesimpulan}

Model knowledge sharing yang digambarkan melalui penelitian ini berdasarkan pola interaksi antar member di dalam Thread Programmer Forum yang pertama yaitu pertama member yang termasuk dalam klasifikasi berdasarkan jumlah postingan dalam Forum Kaskus di kelas menengah ke bawah (member baru atau member yang jarang posting) masih mendominasi jumlahnya dalam membuat thread atau topik bahasan. Member tersebut juga kebanyakan berbeda-beda satu sama lain, dengan kata lain kebanyakan topik bahasan atau thread muncul dari member yang berlainan.

Kedua, komunikasi antar member yang dilihat dari jumlah interaksi yang ada masih sangat sedikit. Jika dilihat dari besarnya jejaring, yakni 535 member, dan relasi yang ada selama bulan Mei 2009, yakni 598 relasi, maka didapat nilai kepadatan jejaring pada Thread Programmer Forum tersebut masih sangat rendah yakni $0.21 \%$ dan juga masih ditemukannya 56 member yang terisolasi atau tidak punya hubungan dengan member lainnya.

Ketiga, dilihat dari derajat keluar dari masing-masing member, bahwa jumlah member yang tergolong tiga besar paling banyak mengirim pesan (sekitar 0.57\%) masih jauh lebih kecil daripada jumlah member yang tidak pernah mengirim pesan sama sekali $(44.67 \%)$, demikian juga jika dilihat dari masuk dari masing-masing member, bahwa jumlah member yang tergolong empat besar paling banyak menerima pesan (sekitar $0.76 \%$ ) masih jauh lebih kecil daripada jumlah member yang tidak pernah menerima pesan sama sekali $(60.56 \%)$.

Keempat komunikasi yang terjadi antar member dalam suatu klasifikasi member, maka pada member yang jumlah postingan-nya sudah termasuk sangat banyak (menengah ke atas) tidak terjadi (pada Kaskus Freak, Kaskus Geek dan Kaskus Holic), melainkan komunikasi antar member banyak terjadi di dalam jejaring member yang termasuk dalam klasifikasi menengah ke bawah (Kaskus Maniac, Kaskuser, Aktivis Kaskus, Kaskus Addict, dan Newbie).

Kelima, dilihat dari analisis terhadap komponen yang membangun jejaring tersebut, maka masih lebih banyak jenis komponen lemah (weak) daripada jenis komponen kuat (strong), yakni 6 berbanding 2. Hal ini menjelaskan bahwa ikatan antar aktor dalam jejaring tersebut masih didominasi oleh komponen-komponen yang memiliki ikatan yang lemah atau tidak terhubung dengan kuat.

Dari model knowledge sharing tersebut, diperoleh kesimpulan bahwa jejaring pada Thread Programmer Forum memang besar dari sisi jumlah aktor, tetapi tidak dalam hal jumlah komunikasi atau hubungan yang ada. Hal ini terlihat dari kepadatan jejaring yang masih sangat rendah nilainya.

Keberhasilan knowledge sharing dalam suatu jejaring sangat bergantung kepada kepadatan jejaring tersebut, karena semakin padat suatu jejaring akan semakin mudah informasi atau pengetahuan tersebar di dalam jejaring tersebut. Jika dalam suatu jejaring diperoleh nilai kepadatan yang tinggi, maka dapat dikatakan bahwa terdapat banyak jumlah komunikasi atau interaksi yang terjadi antar member dalam membagi-bagikan informasi di dalam jejaring tersebut.

Pada umumnya, sebuah forum terdiri dari berbagai macam komunitas yang membentuknya. Dalam mempertahankan keberadaan seorang member maupun suatu komunitas dalam forum, pihak manajemen suatu forum perlu memperhatikan dan mempertimbangkan karakteristik struktural dari forum tersebut seperti struktur komunikasi, tingkat partisipasi dari setiap member atau karakteristik lainnya [4].

Kemampuan pihak manajemen forum untuk mempertahankan suatu komunitas di dalamnya, berdampak pada lamanya waktu seorang member untuk betah menggunakan forum tersebut sebagai 
media untuk mendapatkan maupun menyebarkan informasi. Hal ini tentu berhubungan dengan tingkat kemampuan suatu forum dalam menumbuhkan atau menjaga a sense of $a$ community dalam forum tersebut, yang akhirnya juga menunjukkan kemampuan eksistensi dari forum tersebut.

\section{Referensi}

[1] H.T. Welser, E. Gleave, D. Fisher, \& M. Smith, "Visualizing the Signatures of Social Roles in Online Discussion Groups," Journal of Social Structure, vol. 8, 2009.

[2] Djatmiko \& E. Harmanto, Rahasia Merangkul dan Mempengaruhi Komunitas, SWA,

http://www.swa.co.id/swamajalah/sajian/deta ils.php?cid=1\&id=9968\&pageNum=1, 2009, retrieved November 23, 2009.

[3] L. Freeman, What is Social Network Analysis?, insna,

http://www.insna.org/sna/what.html, 2008, retrieved October 2, 2009.

[4] N.Y. Erlin \& A.A. Rahman, "Students' interactions in online asynchronous discussion forum: A Social Network Analysis" In International Conference on Education Technology and Computer, pp. 25-29, 2009.

[5] P.A.Willging, "Using Social Network Analysis Techniques to Examine Online Interactions," US-China Education Review, vol. 2, pp. 46-56, 2005.

[6] D. Gurteen, "Knowledge, creativity and innovation," Journal of Knowledge Management, vol. 2, pp. 5-13, 1998.

[7] I. Becerra-Fernandez, A. Gonzalez, \& R.
Sabherwal, Knowledge Management: Challenges, Solution, and Technologies, Pearson Prentice Hall, New Jersey, 2004.

[8] T. Amrit. The Knowledge Management Tollkit:Orchestrating IT, Strategy and Knowledge Paltform, Pearson Prentice Hall, New Jersey, 2000.

[9] B. Poonkundran, Knowledge sharing - A good beginning with you, Social Science Research Network, http://ssrn.com/abstract=1513025, 2009, retrieved November 30, 2009.

[10] C.F. Cheung, M.L. Li, W.Y. Shek, W.B. Lee, \& T.S. Tsang, "A systematic approach for knowledge auditing: a case study in transportation sector," Journal of Knowledge Management, vol. 11, pp. 140-158, 2007.

[11] S. Driessen, W. Huijsen, \& M. Grootveld, “A framework for evaluating knowledgemapping tools," Journal of Knowledge Management, vol. 11, pp. 109-117, 2007.

[12] C.V.D. Berg \& I. Popescu, "An experience in knowledge mapping," Journal of Knowledge Management, vol. 9. pp. 123-128, 2005.

[13] S. Ebener, A. Khan, R. Shademani, L. Compernolle, M. Beltran, M.A. Lansang, \& M. Lippmana, "Knowledge mapping as a technique to support knowledge translation," Bulletin of the World Health Organization, vol. 84, pp. 636-642, 2006.

[14] R.A. Hanneman \& M. Riddle, Introduction to social network methods, University of California, Riverside CA, 2005.

[15] U. Kale \& J. Bryant, "Applications of Social Network Analysis in an Online Forum of Teachers" In annual meeting of the International Communication Association, pp. 1-28, 2009. 